\title{
STATE RESERVE AND WARTIME STOCKS OF THE REPUBLIC OF BULGARIA - ESSENCE AND COST
}

\author{
Daniel MANOLOV, Nikolay KAMARASHEV \\ "Vasil Levski" National Military University, Veliko Tarnovo, Bulgaria \\ didosm@abv.bg, nikolay.kamarashev@gmail.com
}

\begin{abstract}
This report presents the importance of the state reserve and the wartime stocks for the national security of our country. The State Reserve and Wartime Stocks State Agency is the object of our research, and the subject of the research is the agency's budget for the period 2015-2018. In this relation, the structure of the agency with its territorial directorates and the structure of costs are examined in detail. The role of the human factor in the agency and its importance for the management of the state reserve and the wartime stocks are presented. A comparative analysis of the individual costs by elements and budget programmes for the period 2015-2018 has been carried out, paying particular attention to the dynamics in their development over the period under review. Some key conclusions have been made concerning the improvement of the management of the state reserve and wartime stocks.
\end{abstract}

\section{Keywords: state reserve, wartime stocks and national security}

\section{Introduction}

The processes of allocation of national resources, in particular for state reserve and wartime stocks, are related to the fact that no government starts from a new page, i.e. there is an established situation which is the result from past decisions.

Despite the often unfavourable environment conditions in the process of planning and allocating national resources, the ones that are crucial when allocating resources are the resources for the state reserve and wartime stocks as they help to guarantee the national security.

\section{Essence of the state reserve and wartime stocks.}

Wartime stocks are stocks of material resources in supply classes intended to meet the needs of the armed forces in a military and war situation for a certain period of time. They are divided into departmental wartime stocks and stocks that are created and maintained in state structures and agencies [1].

Beyond the departmental level of the Ministry of Defence wartime stocks have a wider significance.

Wartime stocks are material resources defined by a nomenclature list and designed to provide, in a situation of war or in a military situation, the military production for the needs of the armed forces, the structures performing defence tasks for the country, the national economy and the population for a period of time, determined by the Council of Ministers with the general state wartime plan [2].

In this respect, the object of research in this paper is the State Reserve and Wartime Stocks State Agency, and the subject of the 
research is the budget of the agency for the period 2015-2018.

In the Republic of Bulgaria, in the interest of national security, a specialised body is established for the implementation of the state policy in the field of accumulation, preservation and utilisation of the state reserves and wartime stocks of the country, and this is the State Reserve and Wartime Stocks State Agency.

The agency has undergone various transformations in its development. It was established in 1950 by Decree No. 591 of a meeting of the National Assembly, promulgated in issue No. 271 of the State Gazette of 17.11.1950, as an independent institution called the Government Supply and State Reserve Bureau.

The Bureau was transformed into State Reserve and Wartime Stocks State Agency on 13.06.2001 with Decree No. 152 of the Council of Ministers.

The rules of procedure of the State Reserve and Wartime Stocks State Agency stipulate that the Chairman of the agency is a firstlevel budget spending authority.

The agency organises and controls the creation, storage, refurbishment, accounting and conservation of state reserves and wartime stocks. The nomenclature and norms for state reserves are proposed by the agency for approval by the Council of Ministers. It also reports its work to the Council of Ministers and the InterMinisterial Council on matters related to the military-industrial complex and the mobilisation readiness of the country.

The State Reserve and Wartime Stocks State Agency stores the following main stocks:

- fuels;

- chemicals;

- foodstuffs;

- ferrous and non-ferrous metals;

- $\quad$ spare parts;

- $\quad$ wood and paper;

- medicines, hospital and sanitary goods;

- appliances and tools, etc.
Of major significance of the abovementioned types of stocks are the fuels, including oil, petroleum products, etc., which are expected to ensure the stability of the energy sector that is consistent with the energy security policy pursued.

The stability of the energy sector as a continuous process of providing vital public services for the functioning of society as a whole, in the face of possible terrorist threats, natural disasters and major industrial accidents, is essential in ensuring national security. Improving energy security as a component of national security is a long-term process requiring investment and sustainable government policy [3].

In this regard, as stocks of particular importance for national security in the Oil and Petroleum Stocks Act, they are classified into the following categories:

- automotive gasoline;

- gas oils, kerosene type jet fuels and diesel fuel;

- boiler fuels;

- propane-butane gas [4].

Only the agency can create targeted stocks of petroleum products. The type, the quantity and the term of maintenance of the target stocks of petroleum products shall be determined by the Council of Ministers on a proposal of the chairman of the agency, which shall be coordinated in advance with the Minister of Economy, Energy and Tourism.

The structure, composition and functions of the State Reserve and Wartime Stocks State Agency are defined by the rules of procedure for the establishment and management of the different types of stocks.

The organisation of the agency's work is carried out according to the rules of procedure, the internal working rules and the instruction for the document flow [5].

The structure of the agency in its broadest form consists of:

- management;

- political office;

- general administration; 
- specialised administration;

- inspectorate;

- internal audit;

- territorial agencies;

- central technical base.

There are six territorial agencies, dislocated in the following towns:

- Sofia;

- Burgas;

- Varna;

- Veliko Tarnovo;

- Plovdiv;

- Pleven.

Each of these territorial agencies has warehouse bases in its area of responsibility. The central technical base is located in the village of Sokolovo in the region of Gabrovo.

\section{Cost of the state reserve and wartime stocks.}

In its development aiming to optimise agency spending, some of its structural elements have been reduced to gain its current structure. These changes in recent years are also imposed by the funds that the state can allocate to the agency's activities as its budget.

The agency's budget for the period 20152018 is presented in Table 1.

\begin{tabular}{|l|l|c|c|c|c|}
\hline № & \multicolumn{1}{|c|}{ Budget } & \multicolumn{1}{|c|}{$\begin{array}{c}2015 \\
\text { /thousand } \\
\text { levs/ }\end{array}$} & $\begin{array}{c}2016 \\
\text { /thousand } \\
\text { levs/ }\end{array}$ & $\begin{array}{c}2017 \\
\text { /thousand } \\
\text { levs/ }\end{array}$ & $\begin{array}{c}2018 \\
\text { /thousand } \\
\text { levs/ }\end{array}$ \\
\hline 1. & Operating expenditure /total/ & 19736.0 & 21132.7 & 21245.3 & 20076.4 \\
\hline 2. & Operating expenditure for staff & 6193.2 & 6193.2 & 6657.6 & 7475.4 \\
\hline 3. & $\begin{array}{l}\text { Operating expenditure for } \\
\text { maintenance }\end{array}$ & 12146.1 & 13542.8 & 13191.0 & 12601.0 \\
\hline 4. & Capital expenditure & 1396.7 & 1396.7 & 1396.7 & 1396.7 \\
\hline 5. & Total expenditure /budget/ & 40365.8 & 40365.8 & 40478.4 & 40706.2 \\
\hline
\end{tabular}

The agency ensures the creating of wartime stocks in accordance with the Public Procurement Act and the Regulation on the Terms and Procedure for Awarding Public Procurements Related to the Defence and Security of the Country, adopted by Decree No. 303 of the Council of Ministers of 2002 (State Gazette, No. 119 of 2002), or with contracts assigns their creating to entrepreneurs and organisations to whom wartime tasks are assigned by an act of the Council of Ministers [6].

In this respect, although information on state reserves and wartime stocks is protected under the Classified Information Protection Act, the publicity and transparency are respected when spending these public funds.
Because of the specificity of the stocks concerned, the number of potential suppliers is very limited.

Analysis of suppliers is key in the analysis of market conditions, as it reveals the weaknesses and problems in the execution of orders, and highlights new features and benefits [7].

In this regard, it can be noted that the market of services directly related to human resources tends to increase in quality and price.

One of the main services that the agency uses and that is directly related to human resources is guarding its strategic sites.

In addition to the costs of various services used by the agency and directly related to human resources, the agency's operating 
expenditures for staff are also significant for its budget.

The operating expenditures for staff of the agency in 2015 are $15.34 \%$ of its budget, and in 2018 they are already $18.36 \%$, even after the changes made by the agency during this period to reduce their organisational structure and reduce the number of its employees. The operating expenditures for staff at the end of the period under review were higher by $3.02 \%$ and were not offset by the corresponding increase in the agency's budget, as the budget for 2018 is $0.83 \%$ higher compared to 2015 , and the total operating expenditure is increased by $1.69 \%$.

The distribution of the expenditures under the budget programmes of the policy in the field of state reserves, wartime stocks and mandatory reserves of oil and petroleum products for the period 2015-2018 is presented in Table 2.

\begin{tabular}{|c|c|c|c|c|c|}
\hline № & Name of the budget programme & $\begin{array}{c}2015 \\
\text { /thousand } \\
\text { levs/ }\end{array}$ & $\begin{array}{c}2016 \\
\text { /thousand } \\
\text { levs/ }\end{array}$ & $\begin{array}{c}2017 \\
\text { /thousand } \\
\text { levs/ }\end{array}$ & $\begin{array}{c}2018 \\
\text { /thousand } \\
\text { levs/ } \\
\end{array}$ \\
\hline 1. & $\begin{array}{l}\text { Budget Programme: State Reserve } \\
\text { and Wartime Stocks }\end{array}$ & 21301.1 & 21193.8 & 21247.3 & 21335.6 \\
\hline 2. & $\begin{array}{l}\text { Budget Programme: Oil and } \\
\text { Petroleum Products Reserve for } \\
\text { Emergency Situations and Target } \\
\text { Reserves of Petroleum Products }\end{array}$ & 19064.7 & 19172.0 & 19231.1 & 19370.6 \\
\hline \multicolumn{2}{|r|}{ TOTAL: } & 40365.8 & 40365.8 & 40478.4 & 40706.2 \\
\hline
\end{tabular}

Table 2 shows that the funds under the State Reserve and Wartime Stocks Budget Programme for the period 2015-2018 are a relatively constant value, and the 2018 increase compared to 2015 is $0.16 \%$, with the most significant expenditure growth under this programme being the operating expenditures for staff, as already mentioned. Planned and spent funds in 2016 and 2017 under the programme as compared to 2015 are less due to the changes made to the agency's organisational structure.

The funds under the Oil and Petroleum Products Reserve for Emergency Situations and Target Reserves of Petroleum Products Budget Programme progressively increase in each subsequent year of the period under review as a result of higher fuel prices at acquisition and their prices at the stage of release of the stocks concerned.

\section{Conclusions.}

The state reserve and wartime stocks management system has a very strong impact not only on the operation of the other subsystems of the society system, but also on its state under real threats to the national security. The management of the reserve in the context of a very limited financial resource implies the prioritisation of the nomenclatures of the material assets to be kept, as well as the release of the stock of material assets that have become unnecessary. The design of the state reserve and wartime stocks management system, as well as any of its transformations, should not be performed in isolation. It should be considered as a subsystem of the national security system, and its seamless integration with the other subsystems is to be ensured to the fullest extent. In addition, the final state of the system must provide it with sufficient flexibility, allowing for adaptation to internal and external changes to the security environment. 


\section{References}

[1] Logistics Doctrine, NP-4, (Sofia, 2012), p. 51

[2] Law on the State Reserves and the Wartime Stocks, Sofia, State Journal, issue 57, 28.07.2015,p. 1

[3] National Security Strategy, Sofia 2011, p. 12

[4] Law for Oil and Petroleum Products Reserves, Sofia, State Jurnal, issue 15, 15.02.2013, p.1

[5] Rules of Procedure of the State Reserve and Wartime Stocks State Agency, (Sofia, State Jurnal, issue 101, 19.12.2017,), p. 19

[6] Regulation for the Terms and Order for Organisation of the Activities on State Reserves and Wartime Stocks, Sofia, State Jurnal, issue 86, 17.10.2014, p. 2

[7] D. Manolov, Directions for Improving the Planning of the Supply with Clothes, Shoes and Equipment in the Bulgarian Army, ISBN 978-973-153-245-5, the $22^{\text {nd }}$ International Scientific Conference, KBO, Sibiu, Romania, 2016, p. 69. 